Published in final edited form as:

Neurochem Res. 2016 April ; 41(4): 677-686. doi:10.1007/s11064-015-1735-6.

\title{
Effects of $I_{3} R 2$ Receptor Deletion in the Ischemic Mouse Retina
}

\author{
Lysann Wagner ${ }^{1}$, Thomas Pannicke ${ }^{1}$, Ina Frommherz ${ }^{1}$, Katja Sauer ${ }^{1}$, Ju Chen ${ }^{2}$, and Antje \\ Grosche $^{3}$ \\ ${ }^{1}$ Paul-Flechsig-Institut für Hirnforschung, Universität Leipzig, Leipzig, Germany \\ ${ }^{2}$ Department of Medicine, University of California San Diego, La Jolla, CA, USA \\ 3Institut für Humangenetik, Universität Regensburg, Franz-Josef-Strauß-Allee 11, 93053 \\ Regensburg, Germany
}

\section{Abstract}

Glial cells in the diseased nervous system undergo a process known as reactive gliosis. Gliosis of retinal Müller glial cells is characterized by an upregulation of glial fibrillary acidic protein and frequently by a reduction of inward $\mathrm{K}^{+}$current amplitudes. Purinergic signaling is assumed to be involved in gliotic processes. As previously shown, lack of the nucleotide receptor $\mathrm{P}_{2} \mathrm{Y}_{1}$ leads to an altered regulation of $\mathrm{K}^{+}$currents in Müller cells of the ischemic retina. Here, we asked first whether this effect is mediated by the $\mathrm{IP}_{3}$ receptor subtype $2\left(\mathrm{IP}_{3} \mathrm{R} 2\right)$ known as the major downstream signaling target of $\mathrm{P}_{2} \mathrm{Y}_{1}$ in Müller cells. The second question was whether lack of $\mathrm{IP}_{3} \mathrm{R} 2$ affects neuronal survival in the control and ischemic retina. Ischemia was induced in wild type and $\mathrm{IP}_{3} \mathrm{R} 2$-deficient $\left(I P_{3} R 2^{--}\right)$mice by transient elevation of the intraocular pressure. Immunostaining and TUNEL labelling were used to quantify neuronal cell loss. The downregulation of inward $\mathrm{K}^{+}$currents in Müller cells from ischemic $I P_{3} R 2^{-1-}$ retinae was less strong than in wild type animals. The reduction of the number of cells in the ganglion cell layer and of calretinin- and calbindin-positive cells 7 days after ischemia was similar in wild type and $I P_{3} R 2^{-1-}$ mice. However, $\mathrm{IP}_{3} \mathrm{R} 2$ deficiency led to an increased number of TUNEL-positive cells in the outer nuclear layer at 1 day and to an enhanced postischemic loss of photoreceptors 7 days after ischemia. This implies that $\mathrm{IP}_{3} \mathrm{R} 2$ is involved in some but not all aspects of signaling in Müller cells after an ischemic insult.

\section{Keywords}

P2Y ${ }_{1}$; IP ${ }_{3}$ 2; Glia; Ischemia; Retina; Mouse

\section{Introduction}

Glial cells, which have long been considered as passive supporting elements of the nervous system, are now well known to be involved in a variety of functions of the nervous tissue. Müller cells are the dominating macroglia of the retina. Recent research revealed several examples how Müller cells interact with neurons and all other elements of the retinal tissue. 
Müller cells control the homeostasis of the extracellular space and provide metabolic support for the neurons, however, they also actively interact with neurons, express a variety of membrane receptors to detect extracellular signals and are able to release gliotransmitters [1]. In virtually all cases of retinal injury and disease, Müller cells undergo a process referred to as reactive gliosis [2,3]. Reactive gliosis has beneficial as well as detrimental effects [4], however, its regulation and possible pharmacological manipulation are not well understood. Reactive Müller cells are characterized by an upregulation of the intermediate filament protein GFAP (glial fibrillary acidic protein) [5] and by a decrease of the amplitude of membrane currents mediated by inwardly rectifying $\mathrm{K}^{+}$(Kir) channels [2]. Moreover, purinergic signaling via $\mathrm{P} 2$ receptors is obviously involved in the development of reactive gliosis in brain and retina [6, 7]. Different subtypes of $\mathrm{P} 2$ receptors are expressed by Müller cells, mainly of the family of metabotropic $\mathrm{P} 2 \mathrm{Y}$ receptors, among them $\mathrm{P}^{2} \mathrm{Y}_{1}$ [7]. $\mathrm{P}_{2} \mathrm{Y}_{1^{-}}$ induced effects in Müller cells are supposed to be mediated by a release of $\mathrm{Ca}^{2+}$ from intracellular stores after activation of the inositol 1,4,5-trisphosphate receptor type $2\left(\mathrm{IP}_{3} \mathrm{R} 2\right)$ [8]. The IP ${ }_{3} \mathrm{R} 2$ is assumed to be glial cell-specific [9], however, ATP-evoked $\mathrm{Ca}^{2+}$ responses in retinal astrocytes are apparently not mediated by $\mathrm{IP}_{3} \mathrm{R} 2[8]$.

Previously, we investigated the functional role of the respective receptors by using mice deficient for the $\mathrm{P}_{2} \mathrm{Y}_{1}$ receptor $\left(P 2 Y_{1}^{-/-}\right)$or the $\mathrm{IP}_{3} \mathrm{R} 2\left(I P_{3} R 2^{-/-}\right)[8,10]$. Both receptors have been demonstrated to be involved in a purinergic volume-regulatory signaling cascade which prevents Müller cell swelling in hypotonic solution. Lack of the receptors resulted in immediate swelling of Müller cell somata in an extracellular solution containing $60 \%$ of control osmolarity [8]. Whereas application of extracellular ATP evoked increases in the intracellular $\mathrm{Ca}^{2+}$ concentration in Müller cells of wild type animals, these reactions were strongly diminished in $\mathrm{IP}_{3} R 2^{-1-}$ mice. It was concluded that activation of $\mathrm{P} 2 \mathrm{Y}_{1}$ receptors and subsequent release of $\mathrm{Ca}^{2+}$ from intracellular stores via $\mathrm{IP}_{3} \mathrm{R} 2$ signaling have an important role in the volume-regulatory function of Müller cells. A malfunctional volume regulation by Müller cells may contribute to neuronal degeneration under osmotic stress conditions. Loss of cellular energy during retinal ischemia may result in dysregulated ionic homeostasis, cell swelling, and cell death [11]. To learn more about a possible function of the $\mathrm{P}_{2} \mathrm{Y}_{1}$ receptor under pathological conditions and, thus, in the development of reactive gliosis, transient retinal ischemia was induced in $P 2 Y_{1}^{-/}$- mice [12]. It turned out that lack of $\mathrm{P}_{2} \mathrm{Y}_{1}$ signaling resulted in a modified activation pattern of Müller cells, a protection of specific neurons in the inner retina and an increased degeneration of photoreceptors. To investigate whether these effects depend on $\mathrm{IP}_{3} \mathrm{R} 2$-mediated signaling pathways, we induced retinal ischemia in $I P_{3} R 2^{-/-}$mice in the present study.

\section{Materials and Methods}

\section{Materials}

Papain was purchased from Roche Molecular Biochemicals (Mannheim, Germany). All other substances were from Sigma-Aldrich (Taufkirchen, Germany), unless stated otherwise. The following primary antibodies were used: rabbit anti-Kir4.1 (1:200; Sigma-Aldrich), mouse anti-GFAP (1:200; G-A-5 clone, Sigma-Aldrich), goat anti-calretinin (1:500, Swant, 
Marly, Switzerland), and mouse anti-calbindin (1:400, Swant). The following secondary antibodies were used: Cy5-conjugated donkey anti-goat, Cy3-conjugated donkey anti-rabbit, Cy2-conjugated donkey anti-mouse, Cy3-conjugated goat anti-rabbit, and Cy2-conjugated goat anti-mouse. All secondary antibodies were applied in a 1:200 dilution and were obtained from Dianova (Hamburg, Germany). For detection of the cell death rate the in situ cell death detection kit, tetramethyl-rhodamine (TMR) red, was applied (Roche Applied Science, Mannheim, Germany).

\section{Animals}

All experiments were done in accordance with the European Communities Council Directive 86/609/EEC and the ARVO Statement for the Use of Animals in Ophthalmic and Vision Research, and were approved by the local authorities. Adult (2-6 months old) animals were maintained with free access to water and food in an air-conditioned room on a 12-h lightdark cycle. $I P_{3} R 2^{--}$mice were validated and characterized as described [13]. They were genotyped by PCR analysis using the following primers: forward, $5^{\prime}$ ACCCTGATGAGGGAAGGTCT-3' ${ }^{\prime}$; reverse, $5^{\prime}$-ATCGATTCATAGGGCACACC- ${ }^{\prime}$ ' for the wild type allele and mutant allele specific primers (forward, $5^{\prime}$ -

AATGGGCTGACCGCTTCCTCGT-3' ${ }^{\prime}$; reverse, $5^{\prime}$-TCTGAGAGTGCCTGGCTTTT- ${ }^{\prime}$ ). Age- and weight-matched littermate wild type controls (129Sv/C57BL/6 background) were used.

\section{Retinal Ischemia}

Transient retinal ischemia was induced in one eye by the HIOP (high intraocular pressure) method. The other eye remained untreated as internal control. Anesthesia was induced with ketamine (100 mg/kg body weight, intraperitoneal (ip); Ratiopharm, Ulm, Germany), xylazine (5 mg/kg, ip; Bayer Vital, Leverkusen, Germany), and atropine sulfate (100 mg/kg, ip; Braun, Melsungen, Germany). The anterior chamber of the test eye was cannulated from the pars plana with a 30-gauge infusion needle, connected to a saline bottle. The intraocular pressure was increased to $160 \mathrm{mmHg}$ for $90 \mathrm{~min}$ by elevating the bottle. After removing the needle, the animals survived for 1 or 7 days and, subsequently, were sacrificed with carbon dioxide.

\section{Preparation of Isolated Müller Cells}

Pieces of isolated retinae were incubated in papain $(0.2 \mathrm{mg} / \mathrm{ml})$-containing $\mathrm{Ca}^{2+}-/ \mathrm{Mg}^{2+}$-free

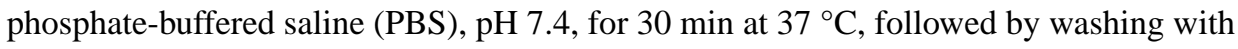
PBS. After short incubation in PBS with DNase I $(200 \mathrm{U} / \mathrm{ml})$, the tissue pieces were triturated by a $1-\mathrm{ml}$ pipette tip, to obtain isolated retinal cells. The cells were stored at $4{ }^{\circ} \mathrm{C}$ in serum-free minimum essential medium until use within $4 \mathrm{~h}$ after cell isolation. Müller cells were identified according to their characteristic morphology.

\section{Whole-Cell Patch-Clamp Records of Isolated Müller Cells}

The whole-cell currents were recorded at room temperature (RT) using the Axopatch 200A amplifier (Axon Instruments, Foster City, CA, USA) and the ISO-2 computer program (MFK, Niedernhausen, Germany). The signals were low-pass filtered at 1 or $6 \mathrm{kHz}$ (eight- 
pole Bessel filter) and digitized at 5 or $30 \mathrm{kHz}$, respectively, using a 12-bit A/D converter. Patch pipettes were pulled from borosilicate glass (Science Products, Hofheim, Germany) and had resistances between 4 and $6 \mathrm{M} \Omega$ when filled with a solution containing (mM) 10 $\mathrm{NaCl}, 130 \mathrm{KCl}, 1 \mathrm{CaCl}_{2}, 2 \mathrm{MgCl}_{2}, 10$ EGTA, and $10 \mathrm{HEPES}$, adjusted to $\mathrm{pH} 7.1$ with Tris. The recording chamber was continuously perfused with extracellular solution that contained (mM) $135 \mathrm{NaCl}, 3 \mathrm{KCl}, 2 \mathrm{CaCl}_{2}, 1 \mathrm{MgCl}_{2}, 1 \mathrm{Na}_{2} \mathrm{HPO}_{4}, 10$ HEPES, and 11 glucose, adjusted to $\mathrm{pH} 7.4$ with Tris. To evoke membrane currents, de- and hyperpolarizing voltage steps of $250 \mathrm{~ms}$ duration, with increments of $10 \mathrm{mV}$, were applied from a holding potential of $-80 \mathrm{mV}$. The amplitude of the steady-state Kir currents was measured at the end of the $250-\mathrm{ms}$ voltage step from -80 to $-140 \mathrm{mV}$. The membrane capacitance of the cells was measured by the integral of the uncompensated capacitive artifact (filtered at $6 \mathrm{kHz}$ ) evoked by a $10-\mathrm{mV}$ voltage step in the presence of extra-cellular $\mathrm{BaCl}_{2}(1 \mathrm{mM})$. Current densities were calculated by dividing inward $\mathrm{K}^{+}$current amplitudes evoked by $60 \mathrm{mV}$ hyperpolarization by the membrane capacitance. The resting membrane potential was measured in the current-clamp mode.

\section{Histological Staining and Immunohistochemistry}

Isolated retinae were fixed in $4 \%$ paraformaldehyde (in PBS) for $2 \mathrm{~h}$. After several washing steps in PBS, the tissues were embedded in PBS containing $3 \%$ agarose (w/v), and $70-\mu \mathrm{m}$ thick slices were cut by using a vibratome. The slices were incubated in $5 \%$ normal goat serum plus $0.3 \%$ Triton X-100 plus $1.0 \%$ dimethylsulfoxide in PBS for two hours at RT and, subsequently, in the primary antibodies overnight at $4{ }^{\circ} \mathrm{C}$. After washing in $1 \%$ bovine serum albumin, the secondary antibodies were applied for $2 \mathrm{~h}$ at RT. Cell nuclei were labeled with TO-PRO-3 (1:1000; Life Technologies, Carlsbad, CA, USA). Control slices were stained without the primary antibody; no unspecific labeling was observed following incubation with the secondary antibody alone (not shown). Images were taken with the laser scanning microscope LSM 510 Meta (Zeiss, Oberkochen, Germany). The numbers of cell nuclei in the ganglion cell (GCL), inner nuclear (INL), or outer nuclear layers (ONL) were counted in a $100-\mu \mathrm{m}$ wide area close to the optic nerve head (optical slice thickness, $1.5 \mu \mathrm{m}$; Fig. 1a). The detectable calretinin fluorescence signal (arbitrary digital units) confined to the whole thickness of the inner plexiform layer (IPL) (excluding associated somata in the GCL or INL) was determined using ImageJ always considering a 460- $\mu \mathrm{m}$ wide area of the central retina. Calretinin-positive and calbindin-positive cells were counted in a 1-mm wide area of retinal slices.

The TUNEL-assay was performed according to the manufacturer's protocol (Roche Applied Science). To assure good accessibility for the components of the assay to the tissue, we subjected free floating retinal slices to a brief microwave treatment in citrate buffer $(\mathrm{pH} 6.0$, $0.1 \mathrm{M}$ ). After washing with PBS and tissue permeabilization for 10 min in $4 \%$ Triton $\mathrm{X}-100$, the slices were incubated for $90 \mathrm{~min}$ in the labeling solution. Afterwards, the slices were counterstained with TO-PRO-3 and mounted onto slides. 


\section{Statistics}

Data are expressed as mean \pm standard error (SEM) or standard deviation (SD, patch clamp data). Statistical analysis was made using Prism (Graphpad Software, San Diego, CA, USA); significance was determined by the non-parametric Mann-Whitney U test.

\section{Results}

\section{Retinal Cell Numbers}

The numbers of cell nuclei in the GCL, INL, and ONL were determined in TO-PRO-3stained retinal slices. In retinae from untreated eyes, no significant differences between wild type and $I P_{3} R 2^{-/-}$mice were found (Fig. 1). Seven days after a transient ischemia of $90 \mathrm{~min}$, the number of cell nuclei was significantly decreased in all nuclear layers in both mouse strains by about $35-62 \%$ (Fig. 1b). Whereas this reduction was similar between both strains in the GCL, it was slightly but significantly different in the INL. A stronger decrease than in wild type mice was found in the ONL of $I P_{3} R 2^{-/-}$animals (Fig. 1b).

It has been described that the time point of peak apoptotic activity in the HIOP-induced rodent retinal ischemia model is 1 day after ischemia [14]. TUNEL staining was used to determine the number of dying cells at 1 day after ischemia. No TUNEL-labeled cell nuclei were found in untreated retinae of both strains (Fig. 2a). In the postischemic retinae, the percentage of TUNEL-positive cells varied between 36 and $57 \%$ of all cells investigated. Whereas the number of TUNEL-positive cells in the GCL and INL was similar for wild type and $I P_{3} R 2^{-/-}$mice, a significantly higher $(P<0.05)$ number of TUNEL-positive photoreceptors was found in the ONL of $I P_{3} R 2^{-1-}$ mice (Fig. 2b) at this time point. The numbers of TUNEL-positive cells at 1 day after ischemia are in accordance with the amount of reduction of cells found after 7 days (Fig. 1b). The data demonstrate that a main mechanism of cell loss observed in the postischemic retinae is ischemia-induced cell death.

\section{Müller Cell Gliosis}

As has been shown before [10], Müller cells were devoid of GFAP in control retinal slices from wild type and $I P_{3} R 2^{-1-}$ mice (Fig. 3a). Only astrocytes in the GCL display GFAP immunoreactivity in the untreated retina (Fig. 3a). In the postischemic retina, a strongly increased GFAP staining was observed in the GCL. Moreover, immunolabeling could be found in Müller cell stalks in the IPL and in some cells even over their entire length in wild type as well as $I P_{3} R 2^{-/-}$retinae (Fig. 3a).

It has been shown that the Kir channel subtype Kir4.1 mediates a large part of the membrane currents in Müller cells [15]. Immunostaining for Kir4.1 can be found particularly in the endfeet of Müller cells and in glial processes that surround blood vessels [15, 16]. As has been shown before [10], this distribution was not altered in untreated $I P_{3} R 2^{-1-}$ mice (Fig. $3 b)$. In the postischemic retina, the Kir4.1 immunoreactivity was more evenly distributed and obviously downregulated in retinae from wild type as well as from $I P_{3} R 2^{-/-}$mice (Fig. $3 b)$. 
In many (but not all) cases of retinal degeneration, Müller cells display specific alterations of physiological properties. After transient ischemia of the murine retina, a decrease in the amplitude of inward $\mathrm{K}^{+}$currents has been described [17]. In our present study, this finding could be confirmed. Depolarizing and hyperpolarizing voltage steps evoked outward and inward currents, respectively, in isolated Müller cells (Fig. 4). Application of the Kir channel blocker $\mathrm{Ba}^{2+}(0.3$ and $1 \mathrm{mM})$ decreased outward currents and blocked inward currents almost completely (data not shown). Therefore, it can be concluded that inward currents are mainly mediated by $\mathrm{Ba}^{2+}$-sensitive Kir channels. Seven days after ischemia, the complete membrane currents of Müller cells were reduced (Fig. 4). Typical current patterns of individual cells and mean current-voltage relationships are shown in Fig. 4. The amplitude of inward $\mathrm{K}^{+}$currents recorded from postischemic Müller cells at a hyperpolarizing step of $60 \mathrm{mV}$ was decreased to $35 \pm 22 \%$ of the control value in wild type mice (Table 1). In Müller cells from $I P_{3} R 2^{-1-}$ mice a clear but significantly less pronounced decrease to 47 $\pm 24 \%$ of the control value has been observed after ischemia (Table 1). The current densities were decreased in both strains with higher postischemic values in $I P_{3} R 2^{-1-}$ mice compared to wild type mice (Table 1). The membrane potential displayed a slight decrease, whereas the membrane capacitance was increased in cells of both strains (Table 1).

\section{Effects on Specific Retinal Neurons}

In a previous study, we investigated the effects of transient retinal ischemia on retinal neurons in mice deficient in the $\mathrm{P}_{2} \mathrm{Y}_{1}$ receptor [12]. Because a possible pathway of $\mathrm{P}_{2} \mathrm{Y}_{1}$ signaling is via activation of intracellular $\mathrm{IP}_{3}$ receptors, we assumed that lack of $\mathrm{IP}_{3} \mathrm{R} 2$ may cause similar effects. We studied this point by immunostaining retinal slices with antibodies against the cell-specific proteins calretinin (amacrine cells) and calbindin (horizontal cells) (Fig. 5). Calretinin-positive cells were found in the GCL and INL, moreover, the IPL displayed three distinct calretinin-positive bands. Calbindin-positive cell somata were located in the INL. After transient ischemia, the numbers of calretinin-positive cells and calbindin-positive cells as well as the intensity of calretinin immunoreactivity in the IPL were strongly downregulated (Fig. 5). In contrast to the data from $\mathrm{P}_{2} \mathrm{Y}_{1}$-deficient mice, we observed no significant differences in the number of calretinin- and calbindin-positive (i.e., amacrine and horizontal) cells between wild type and $I P_{3} R 2^{---}$mice, neither in the control nor in the postischemic retina.

\section{Discussion}

There were two main questions that should be answered by the described experiments: First, whether the downregulation of $\mathrm{K}^{+}$currents typical for Müller cell gliosis is affected by the lack of $\mathrm{IP}_{3} \mathrm{R} 2$, and second, whether $\mathrm{IP}_{3} \mathrm{R} 2$ deficiency has any effect on neuronal survival. The responses are: (1) downregulation of $\mathrm{K}^{+}$currents is less strong in $I P_{3} R 2^{-/-}$mice, and (2) photoreceptors display an enhanced postischemic loss in $I P_{3} R 2^{-/-}$mice whereas the number of neurons in the inner retina is similarly reduced after ischemia in wild type and $I P_{3} R 2^{-1-}$ mice.

A detailed morphological analysis of the untreated retina of $I P_{3} R 2^{-1-}$ mice revealed no significant alterations due to $\mathrm{IP}_{3} \mathrm{R} 2$ deficiency. This is in agreement with an earlier study 
[10]. Whereas previously only the general morphology and the expression of Müller cellspecific proteins have been studied, we performed now a detailed quantitative analysis of the cell numbers in the retinal layers including the use of neuron-specific markers. In a similar approach using $P 2 Y_{1}^{-/-}$mice, we found little but significantly decreased cell numbers in the GCL and INL [12]. Lack of $\mathrm{P}_{2} \mathrm{Y}_{1}$ obviously causes a disturbed retinal development and/or a slow neuronal degeneration. The current data suggest that $\mathrm{IP}_{3} \mathrm{R} 2$-mediated $\mathrm{Ca}^{2+}$ release is not involved in the aberrations found before in the $P 2 Y_{1}^{-/-}$retina. As mentioned above, retinal astrocytes from $I P_{3} R 2^{-/-}$mice displayed ATP-evoked $\mathrm{Ca}^{2+}$-responses [8], demonstrating the existence of $\mathrm{IP}_{3} \mathrm{R} 2$-independent signalling mechanisms. Therefore, a compensatory upregulation of such pathways in retinal astrocytes of $I P_{3} R 2^{-1-}$ mice cannot be excluded.

Contrary to the untreated retina, differences between the retinae of $I P_{3} R^{-/-}$and wild type mice were observed after transient ischemia. As shown by TUNEL staining, the number of dying photoreceptors 1 day after ischemia was increased in $I P_{3} R 2^{-/-}$mice, resulting in significantly lower photoreceptor numbers after 7 days. However, the numbers of calretininand calbindin-positive cells in the inner retina were not different to the wild type. This is again in contrast to $P 2 Y_{1}^{-/-}$mice, where these specific inner retinal neurons displayed a better survival after ischemia compared with the wild type [12]. Obviously, $\mathrm{IP}_{3} \mathrm{R} 2$-induced $\mathrm{Ca}^{2+}$ mobilization is potentially involved in mediating protective effects (of $\mathrm{P}_{2} \mathrm{Y}_{1}$ signaling) in the interaction between Müller cells and photoreceptors but not between Müller cells and neurons of the inner retina, e.g., amacrine cells.

Purinergic signaling is known to be involved in the induction of reactive gliosis [6, 7]. Among a variety of alterations, a decrease of inward $\mathrm{K}^{+}$current amplitudes has been observed in several cases of Müller cell gliosis [2, 17, 18]. This effect was strongly attenuated in $P 2 Y_{1}^{-l-}$ mice. The relative inward $\mathrm{K}^{+}$current amplitudes decreased to $82 \% 7$ days after an ischemic insult of $90 \mathrm{~min}$ [12]. In wild type animals, the currents decreased under the same conditions to about one-third of the control value. In $I P_{3} R 2^{-1-}$ mice an intermediate effect was recorded: the inward $\mathrm{K}^{+}$current amplitude decreased to $47 \%$. Although these data do not elucidate the exact pathway from $\mathrm{P}_{2} \mathrm{Y}_{1}$ receptors to Kir channel function, it is suggested that the effect of $\mathrm{P}_{2} \mathrm{Y}_{1}$ signaling on the Kir channels is partially dependent on intracellular $\mathrm{Ca}^{2+}$ mobilization mediated by $\mathrm{IP}_{3} \mathrm{R} 2$.

The finding that glial cells play a more active role than has been supposed for many years resulted in new hypotheses describing neuron-glia interactions. For example, the concept of the tripartite synapse suggests that glial cells respond to neuronal activity with an increase in intracellular $\mathrm{Ca}^{2+}$, which may trigger the release of glio-transmitters [19]. A role of astrocytic $\mathrm{Ca}^{2+}$ signals for the functional integrity of tripartite synapses has been described [20]. Activation of different $\mathrm{G}_{\mathrm{q}}$-linked $\mathrm{G}$ protein-coupled receptors results in the release of $\mathrm{Ca}^{2+}$ from intracellular stores mediated by the activation of $\mathrm{IP}_{3}$ receptors. Glial cells express $\mathrm{IP}_{3} \mathrm{R} 2$ [9] and $\mathrm{IP}_{3} \mathrm{R} 2$-deficient mice have been generated and used in several studies. Surprisingly, these animals appear healthy, breed well, do not show obvious histological and behavioural abnormalities, and live normal lifespans [21]. There is an ongoing debate 
regarding the effect of $\mathrm{IP}_{3} \mathrm{R} 2$ knockout on neuronal activity. Petravicz et al. [21] demonstrated that lack of $\mathrm{IP}_{3} \mathrm{R} 2$ blocked spontaneous and $\mathrm{G}$ protein-mediated astrocytic $\mathrm{Ca}^{2+}$ increases. However, the baseline synaptic activity of CA1 pyramidal neurons in the hippocampus was not affected. Similarly, Agulhon et al. [22] described that obliteration of astrocytic $\mathrm{Ca}^{2+}$ increases in $\mathrm{IP}_{3} \mathrm{R} 2$-deficient mice did not affect excitatory synaptic transmission or synaptic plasticity, suggesting that the mechanisms of gliotransmitter release should be reconsidered. Contrariwise, it was observed that somatosensory plasticity in mouse barrel cortex could not be induced in $\mathrm{IP}_{3} \mathrm{R} 2$-deficient mice [23]. Navarrete et al. [24] demonstrated that cholinergic long-term potentiation was absent in $I P_{3} R 2^{-/-}$mice. These representative examples demonstrate that neuron-glia interactions and the role of gliotransmission are currently not completely understood. This might be caused by the variability of experimental approaches: different methods are used to study different brain regions and different neuronal circuits. A new study may help to understand the role of glial $\mathrm{Ca}^{2+}$ signaling [25]. Using genetically encoded $\mathrm{Ca}^{2+}$ indicators, the authors found a previously unknown form of glial $\mathrm{Ca}^{2+}$ signaling that is independent of $\mathrm{IP}_{3} \mathrm{R} 2$. It remains to be investigated whether a similar component exists in retinal Müller cells. $I P_{3} R 2^{-/-}$mice have also been used in a recent study of effects after neocortical stab wound injury [26]. The authors described that the $\mathrm{IP}_{3} \mathrm{R} 2$ deficiency resulted in an impaired reactive astrogliosis and an increased injury-associated neuronal death. The latter finding is in agreement with our observation of increased photoreceptor death.

In our current study, we investigated the role of $\mathrm{IP}_{3} \mathrm{R} 2$-mediated glial activity on some specific features of retinal morphology and physiology under healthy and pathological conditions. Our methods do not allow to draw precise conclusions regarding the effect of $\mathrm{Ca}^{2+}$-dependent glio-transmitter release on neuronal activity. However, we present evidence for a modulated reactive Müller cell gliosis after transient retinal ischemia in $I P_{3} R 2^{-1-}$ mice, although this effect is weaker than observed before in $P 2 Y_{1}^{-/}$mice [12]. Our data suggest that the protective effect of $\mathrm{P}_{2} \mathrm{Y}_{1}$ signaling in Müller cells on the photoreceptor survival is not only mediated by $\mathrm{IP}_{3} \mathrm{R} 2$-dependent mechanisms. It has been shown previously that in Müller cells from control wild type mice a glutamatergic-purinergic signaling cascade leads to the release of adenosine [8]. Neuronal activity can be inhibited by adenosine [27]. This inhibition may be neuroprotective in the outer retina where photoreceptors release glutamate which may not only activate postsynaptic bipolar cells but also the signaling cascade of Müller cells. $\mathrm{IP}_{3} \mathrm{R} 2$-mediated $\mathrm{Ca}^{2+}$ increases are a required step in the signaling cascade in murine Müller cells [10], their lack should interrupt the signaling pathway, thus preventing the release of adenosine. This may cause increased photoreceptor damage in the postischemic retina, as was hypothesized in the model of $P 2 Y_{1}^{-/}$mice [12].

Neuroprotective effects of $\mathrm{P} 2 \mathrm{Y}$ receptor-stimulated $\mathrm{IP}_{3}$-mediated $\mathrm{Ca}^{2+}$ release in astrocytes have also been shown in an in vitro study where the $\mathrm{IP}_{3}$ receptor was inhibited pharmacologically [28]. In $I P_{3} R 2^{-/-}$mice not only the purinergic signaling but also other pathways where intracellular $\mathrm{Ca}^{2+}$ increases are involved should be disturbed. Our data demonstrate that such pathways contribute to the Müller cell support of photoreceptors under pathological conditions. Future studies are needed to clarify in more detail which $\mathrm{IP}_{3} \mathrm{R} 2$-dependent Müller cell functions are involved in photoreceptor protection. 


\section{Acknowledgments}

Supported by Deutsche Forschungsgemeinschaft (FOR 748, GRA4403/1-1 to A.G., RE 849/16-1, PA 615/2-1 to T.P.) and the PRO RETINA-Stiftung to A.G. Dirkje Felder is thanked for excellent technical assistance.

\section{References}

1. Reichenbach A, Bringmann A (2013) New functions of Müller cells. Glia 61:651-678 [PubMed: 23440929]

2. Bringmann A, Pannicke T, Grosche J, Francke M, Wiedemann P, Skatchkov SN, Osborne NN, Reichenbach A (2006) Müller cells in the healthy and diseased retina. Prog Retin Eye Res 25:397424 [PubMed: 16839797]

3. Bringmann A, Iandiev I, Pannicke T, Wurm A, Hollborn M, Wiedemann P, Osborne NN, Reichenbach A (2009) Cellular signaling and factors involved in Müller cell gliosis: neuroprotective and detrimental effects. Prog Retin Eye Res 28:423-451 [PubMed: 19660572]

4. Sofroniew MV (2009) Molecular dissection of reactive astrogliosis and glial scar formation. Trends Neurosci 32:638-647 [PubMed: 19782411]

5. Lewis GP, Fisher SK (2003) Up-regulation of glial fribrillary acidic protein in response to retinal injury: its potential role in glial remodeling and a comparison to vimentin expression. Int Rev Cytol 230:263-290 [PubMed: 14692684]

6. Franke H, Krügel U, Schmidt R, Grosche J, Reichenbach A, Illes P (2001) P2 receptor-types involved in astrogliosis in vivo. Br J Pharmacol 134:1180-1189 [PubMed: 11704637]

7. Wurm A, Pannicke T, Iandiev I, Francke M, Hollborn M, Wiedemann P, Reichenbach A, Osborne NN, Bringmann A (2011) Purinergic signaling involved in Müller cell function in the mammalian retina. Prog Retin Eye Res 30:324-342 [PubMed: 21689780]

8. Wurm A, Lipp S, Pannicke T, Linnertz R, Krügel U, Schulz A, Färber K, Zahn D, Grosse J, Wiedemann P, Chen J, Schöneberg T, Illes P, Reichenbach A, Bringmann A (2010) Endogenous purinergic signaling is required for osmotic volume regulation of retinal glial cells. J Neurochem 112:1261-1272 [PubMed: 20002522]

9. Sharp AH, Nucifora FC Jr, Blondel O, Sheppard CA, Zhang C, Snyder SH, Russell JT, Ryugo DK, Ross CA (1999) Differential cellular expression of isoforms of inositol 1,4,5-triphosphate receptors in neurons and glia in brain. J Comp Neurol 406: 207-220 [PubMed: 10096607]

10. Lipp S, Wurm A, Pannicke T, Wiedemann P, Reichenbach A, Chen J, Bringmann A (2009) Calcium responses mediated by type $2 \mathrm{IP}_{3}$-receptors are required for osmotic volume regulation of retinal glial cells in mice. Neurosci Lett 457:85-88 [PubMed: 19429168]

11. Osborne NN, Casson RJ, Wood JP, Chidlow G, Graham M, Melena J (2004) Retinal ischemia: mechanisms of damage and potential therapeutic strategies. Prog Retin Eye Res 23: 91-147 [PubMed: 14766318]

12. Pannicke T, Frommherz I, Biedermann B, Wagner L, Sauer K, Ulbricht E, Härtig W, Krügel U, Ueberham U, Arendt T, Illes P, Bringmann A, Reichenbach A, Grosche A (2014) Differential effects of $\mathrm{P}_{2} \mathrm{Y}_{1}$ deletion on glial activation and survival of photoreceptors and amacrine cells in the ischemic mouse retina. Cell Death Dis 5:e1353 [PubMed: 25077539]

13. Li X, Zima AV, Sheikh F, Blatter LA, Chen J (2005) Endothelin-1-induced arrhythmogenic $\mathrm{Ca}^{2+}$ signaling is abolished in atrial myocytes of inositol-1,4,5-trisphosphate $\left(\mathrm{IP}_{3}\right)$-receptor type 2deficient mice. Circ Res 96:1274-1281 [PubMed: 15933266]

14. Kuroiwa S, Katai N, Shibuki H, Kurokawa T, Umihira J, Nikaido T, Kametani K, Yoshimura N (1998) Expression of cell cycle-related genes in dying cells in retinal ischemic injury. Invest Ophthalmol Vis Sci 39:610-617 [PubMed: 9501873]

15. Kofuji P, Ceelen P, Zahs KR, Surbeck LW, Lester HA, Newman EA (2000) Genetic inactivation of an inwardly rectifying potassium channel (Kir4.1 subunit) in mice: phenotypic impact in retina. $\mathrm{J}$ Neurosci 20:5733-5740 [PubMed: 10908613]

16. Ishii M, Horio Y, Tada Y, Hibino H, Inanobe A, Ito M, Yamada M, Gotow T, Uchiyama Y, Kurachi Y (1997) Expression and clustered distribution of an inwardly rectifying potassium channel, 
$\mathrm{K}_{\mathrm{AB}}$-2/Kir4.1, on mammalian retinal Müller cell membrane: their regulation by insulin and laminin signals. J Neurosci 17:7725-7735 [PubMed: 9315894]

17. Hirrlinger PG, Ulbricht E, Iandiev I, Reichenbach A, Pannicke T (2010) Alterations in protein expression and membrane properties during Müller cell gliosis in a murine model of transient retinal ischemia. Neurosci Lett 472:73-78 [PubMed: 20132867]

18. Bringmann A, Francke M, Pannicke T, Biedermann B, Kodal H, Faude F, Reichelt W, Reichenbach A (2000) Role of glial $\mathrm{K}^{+}$channels in ontogeny and gliosis: a hypothesis based upon studies on Müller cells. Glia 29:35-44 [PubMed: 10594921]

19. Araque A, Parpura V, Sanzgiri RP, Haydon PG (1999) Tripartite synapses: glia, the unacknowledged partner. Trends Neurosci 22:208-215 [PubMed: 10322493]

20. Tanaka M, Shih P-Y, Gomi H, Yoshida T, Nakai J, Ando R, Furuichi T, Mikoshiba K, Semyanov A, Itohara $S$ (2013) Astrocytic $\mathrm{Ca}^{2+}$ signals are required for the functional integrity of tripartite synapses. Mol Brain 6:6 [PubMed: 23356992]

21. Petravicz J, Fiacco TA, McCarthy KD (2008) Loss of $\mathrm{IP}_{3}$ receptor-dependent $\mathrm{Ca}^{2+}$ increases in hippocampal astrocytes does not affect baseline CA1 pyramidal neuron synaptic activity. J Neurosci 28:4967-4973 [PubMed: 18463250]

22. Agulhon C, Fiacco TA, McCarthy KD (2010) Hippocampal short- and long-term plasticity are not modulated by astrocyte $\mathrm{Ca}^{2+}$ signaling. Science 327:1250-1254 [PubMed: 20203048]

23. Takata N, Mishima T, Hisatsune C, Nagai T, Ebisui E, Mikoshiba K, Hirase H (2011) Astrocyte calcium signaling transforms cholinergic modulation to cortical plasticity in vivo. J Neurosci 31:18155-18165 [PubMed: 22159127]

24. Navarrete M, Perea G, Fernandez de Sevilla D, Gómez-Gonzalo M, Núnez A, Martin ED, Araque A (2012) Astrocytes mediate in vivo cholinergic-induced synaptic plasticity. PLoS Biol 10:e1001259 [PubMed: 22347811]

25. Srinivasan R, Huang BS, Venugopal S, Johnston AD, Chai H, Zeng H, Golshani P, Khakh BS (2015) $\mathrm{Ca}^{2+}$ signalling in astrocytes from $I p 3 r 2^{-1-}$ mice in brain slices and during startle responses in vivo. Nat Neurosci 18:708-717 [PubMed: 25894291]

26. Kanemaru K, Kubota J, Sekiya H, Hirose K, Okubo Y, Iino M (2013) Calcium-dependent Ncadherin up-regulation mediates reactive astrogliosis and neuroprotection after brain injury. Proc Natl Acad Sci USA 110:11612-11617 [PubMed: 23798419]

27. Newman EA (2003) Glial cell inhibtion of neurons by release of ATP. J Neurosci 23:1659-1666 [PubMed: 12629170]

28. Wu J, Holstein JD, Upadhyay G, Lin D-T, Conway S, Muller E, Lechleiter JD (2007) Purinergic receptor-stimulated $\mathrm{IP}_{3}$-mediated $\mathrm{Ca}^{2+}$ release enhances neuroprotection by increasing astrocyte mitochondrial metabolism during aging. J Neurosci 27:6510-6520 [PubMed: 17567812] 

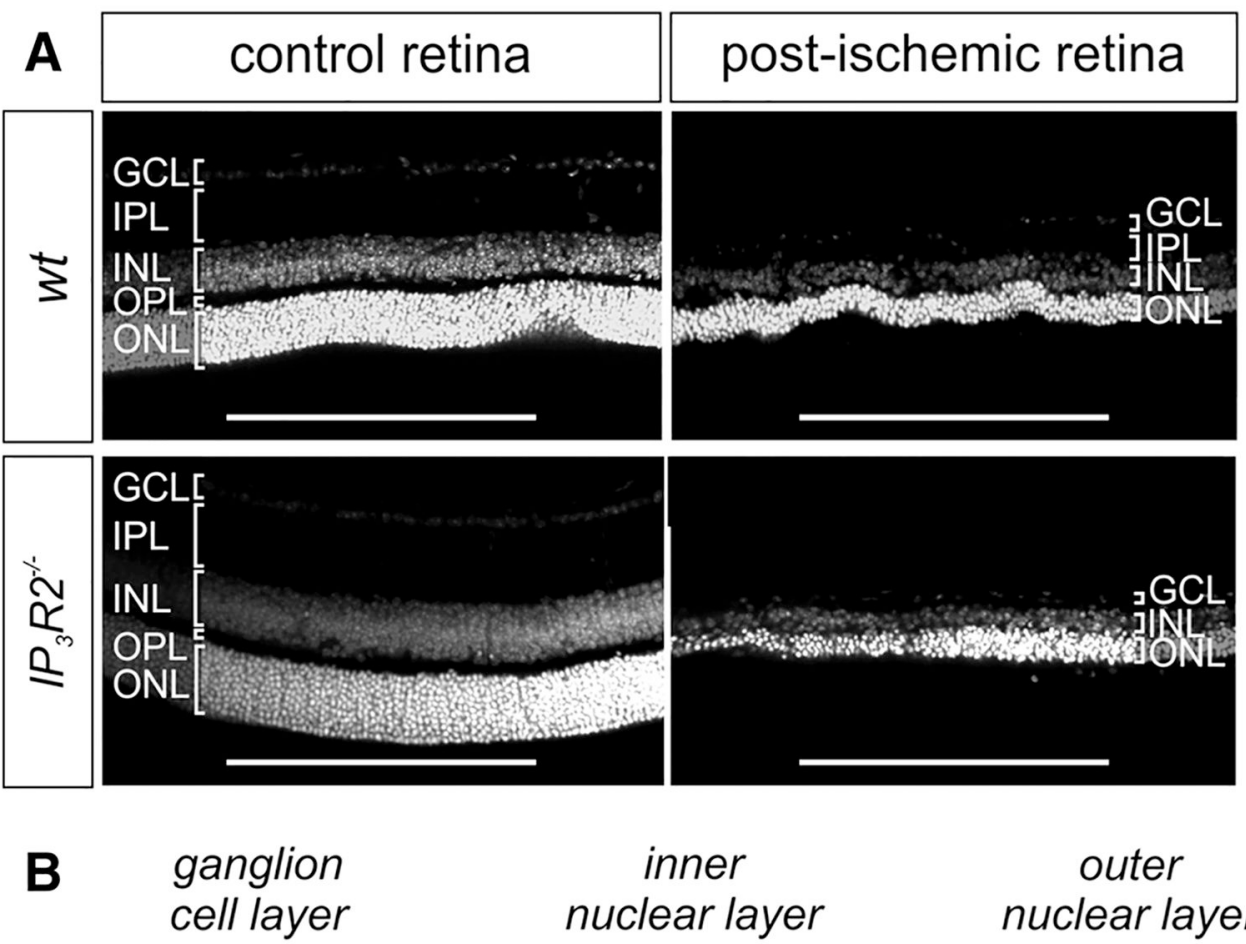

outer
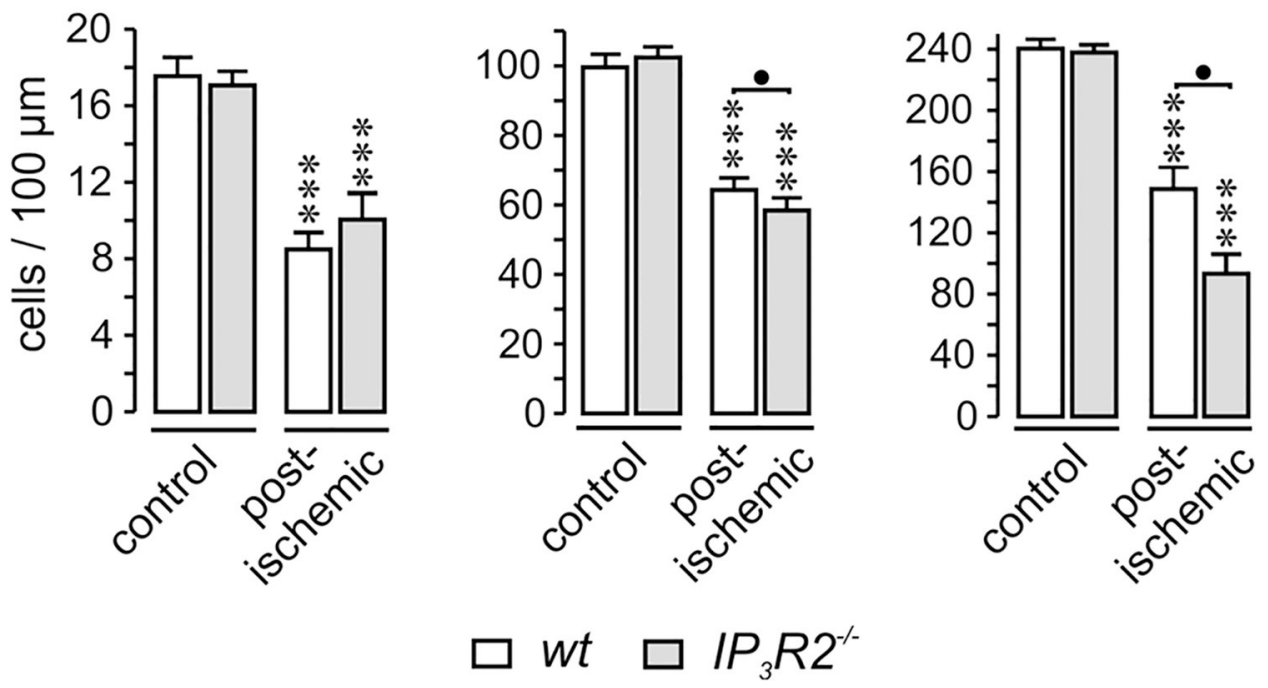

Fig. 1.

Ischemic degeneration of the murine retina. The data were obtained in retinal slices from wild type (wt) and $I P_{3} R 2^{-/-}$mice. The tissues were isolated 7 days after transient retinal ischemia of $90 \mathrm{~min}$. a The counting of cell nuclei was performed in a 100- $\mu \mathrm{m}$ wide area close to the optic nerve head. Cell nuclei were labeled with TO-PRO-3. Scale bars $100 \mu \mathrm{m}$. $G C L$ ganglion cell layer, $I N L$ inner nuclear layer, $I P L$ inner plexiform layer, $O N L$ outer nuclear layer, $O P L$ outer plexiform layer. b Mean \pm SEM number of cell nuclei in different retinal layers. Significant differences compared to the respective control eyes of the same genotype: $* * * P<0.001$. Significant differences between the strains: ${ }^{\bullet} P<0.05$. Data were obtained from 4 to 6 animals. From each animal 4-6 central slices were analysed leading to $\mathrm{n}=17-33$ 

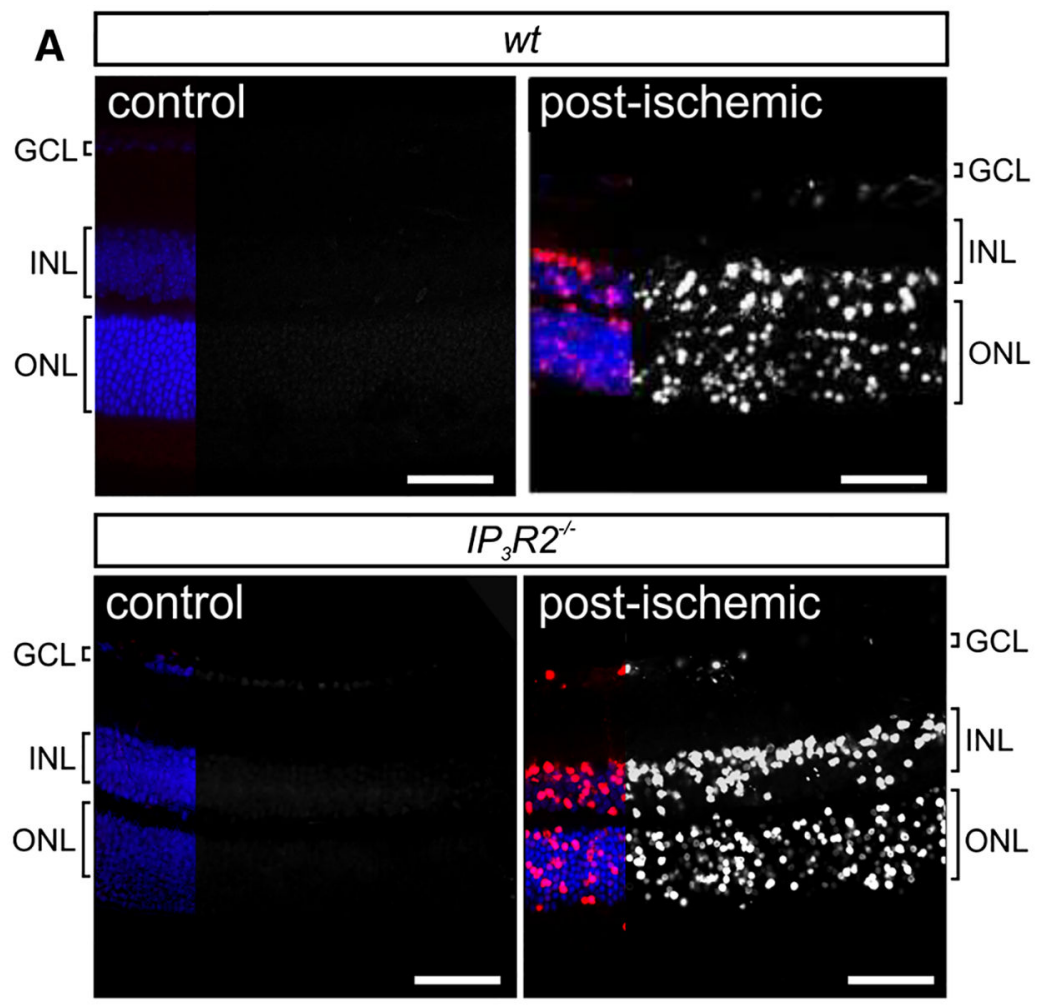

\section{B}

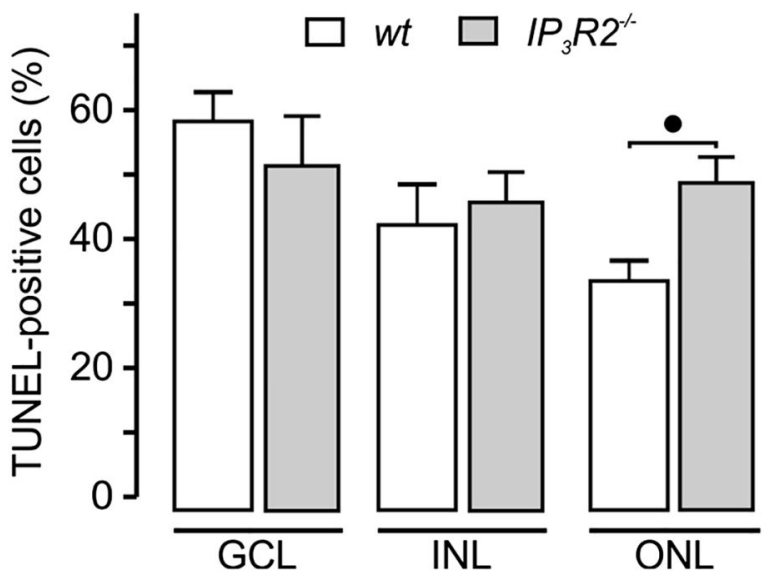

Fig. 2.

Cell death determined with TUNEL staining of retinal slices from wild type $(w t)$ and $I P_{3} R 2^{-/-}$mice. The tissues were isolated 1 day after transient retinal ischemia of $90 \mathrm{~min}$. a Representative images demonstrating staining of all cell nuclei (blue in the left parts of the images) and of TUNEL-labeled nuclei (red in the left parts and white in the right parts of the images) in retinae from $w t$ and $I P_{3} R 2^{-/-}$mice. No TUNEL-labeled nuclei were found in untreated control retinae. After ischemia, TUNEL-labeled nuclei were found in all nuclear layers of the retinae. Bars $50 \mu \mathrm{m}$. b Mean \pm SEM percentage of TUNEL-labeled cell nuclei in the ganglion cell (GCL), inner nuclear (INL) and outer nuclear layers (ONL). ${ }^{\bullet} P<0.05$. TUNEL-positive cells were determined in 13-18 central retinal slices derived from 4 to 5 animals (Color figure online) 
A

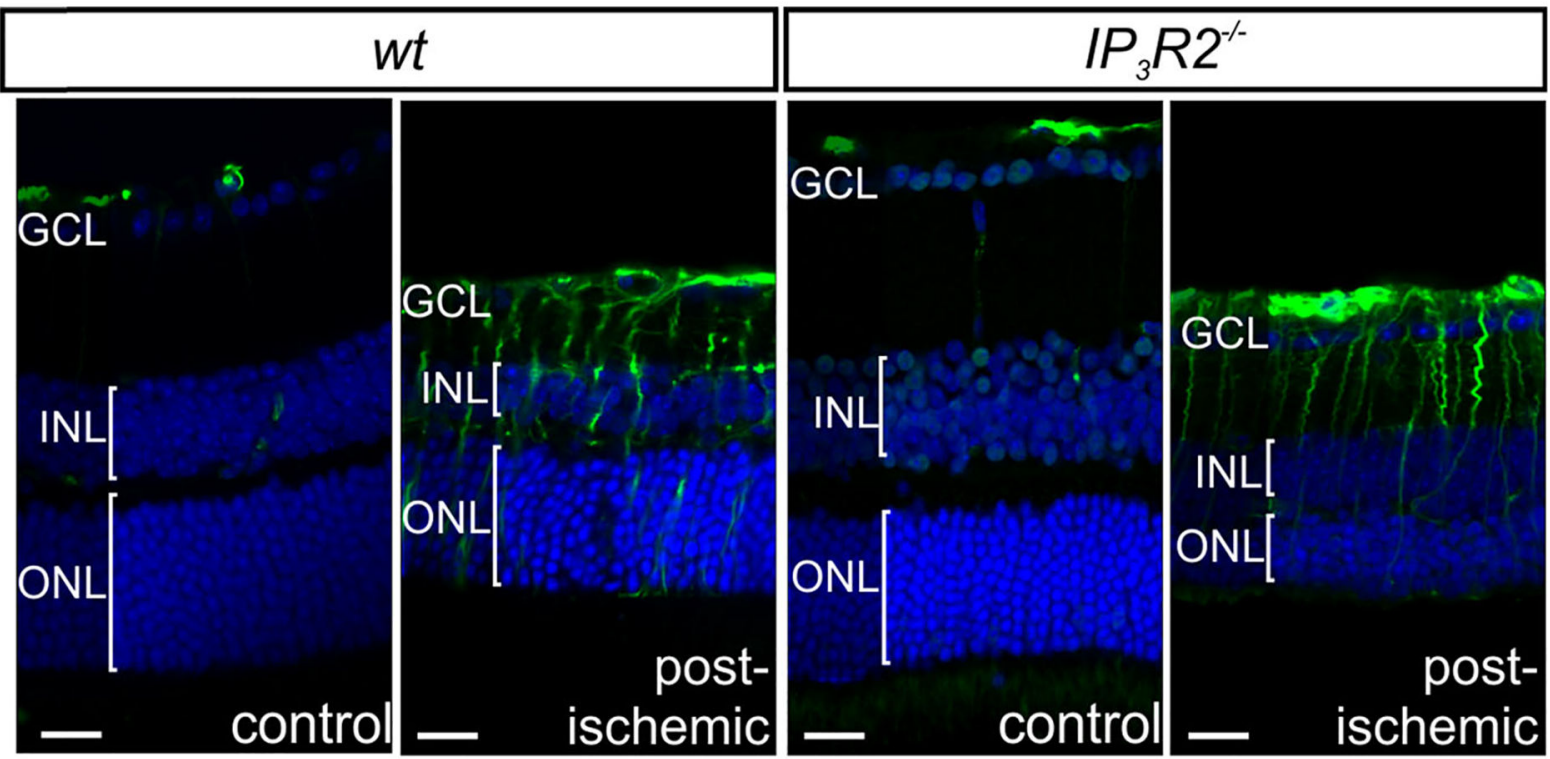

B

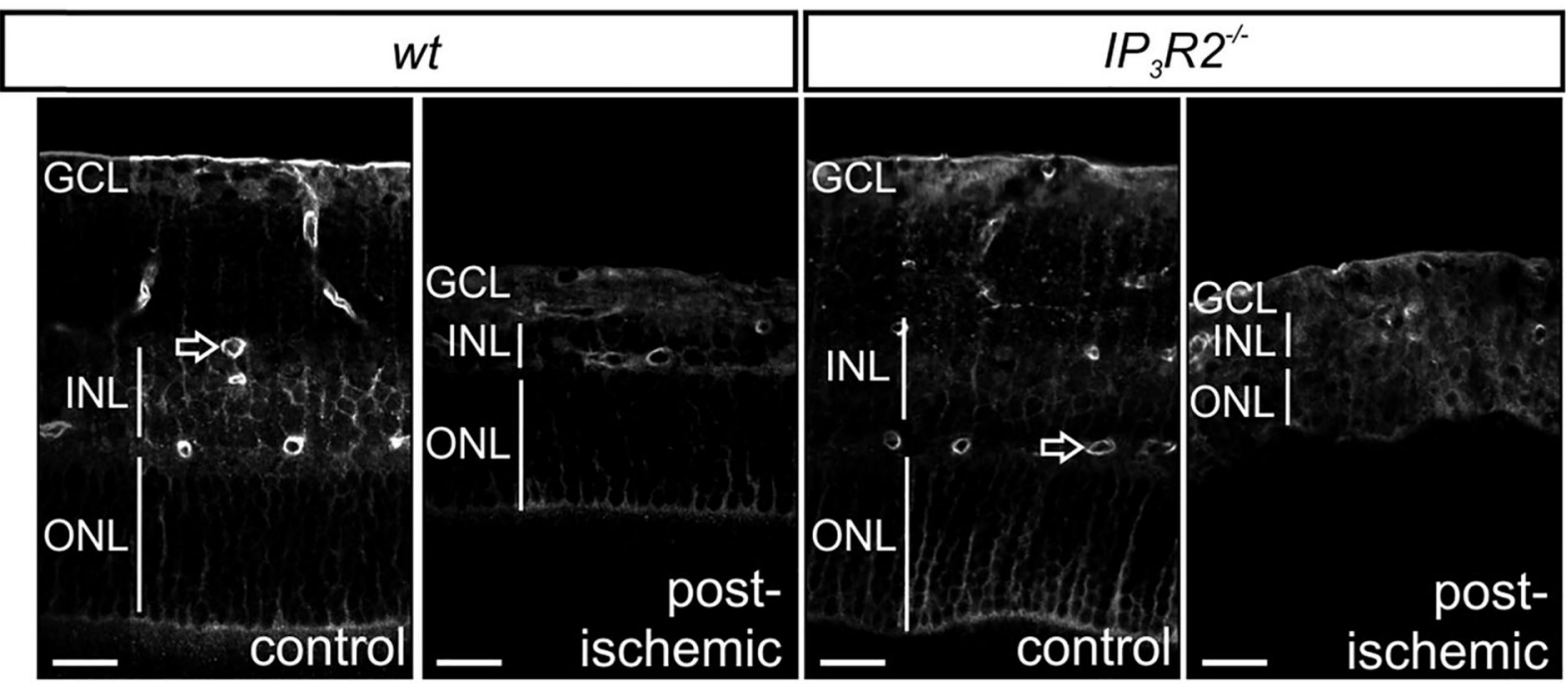

Fig. 3.

Ischemia-induced Müller cell gliosis in the retinae of wild type ( $w t$ ) and $I P_{3} R 2^{-/-}$mice. a GFAP immunoreactivity (green) in slices of retinae isolated 7 days after transient retinal ischemia of $90 \mathrm{~min}$. Labeling of cell nuclei (blue) revealed reduced cell numbers in all nuclear layers. $G C L$ ganglion cell layer, $I N L$ inner nuclear layer, $O N L$ outer nuclear layer. b Distribution of Kir4.1 immunoreactivity in slices of control retinae and of retinae obtained 7 days after transient retinal ischemia of 90 min. Unfilled arrow, perivascular Kir4.1 labeling. Scale bars $20 \mu \mathrm{m}$ (Color figure online) 
A

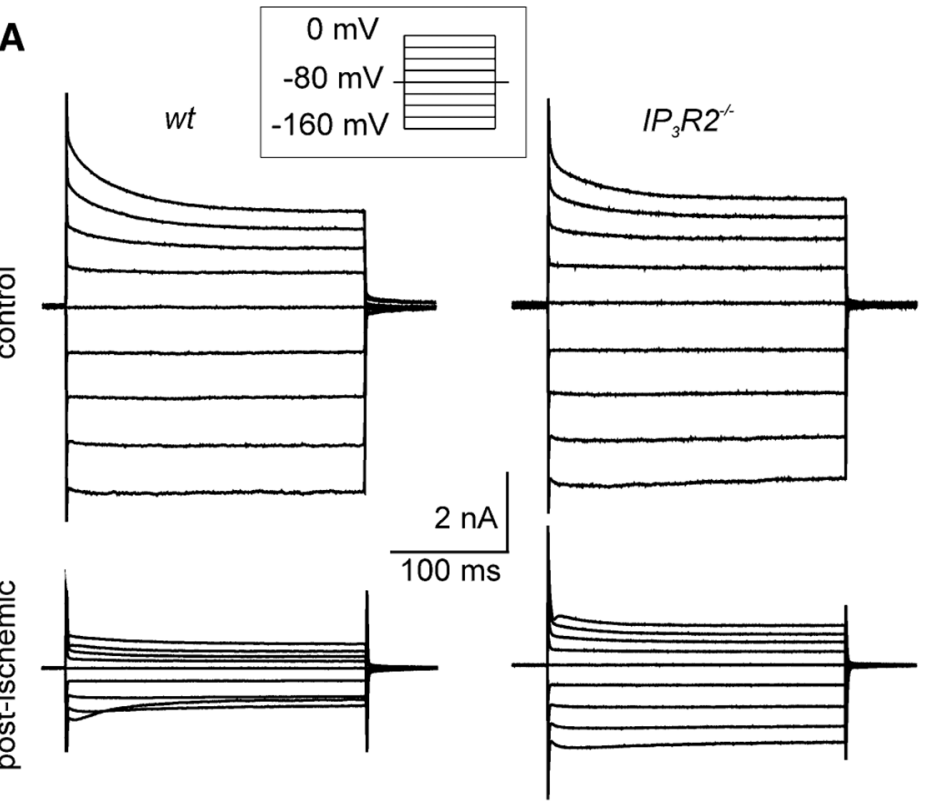

B
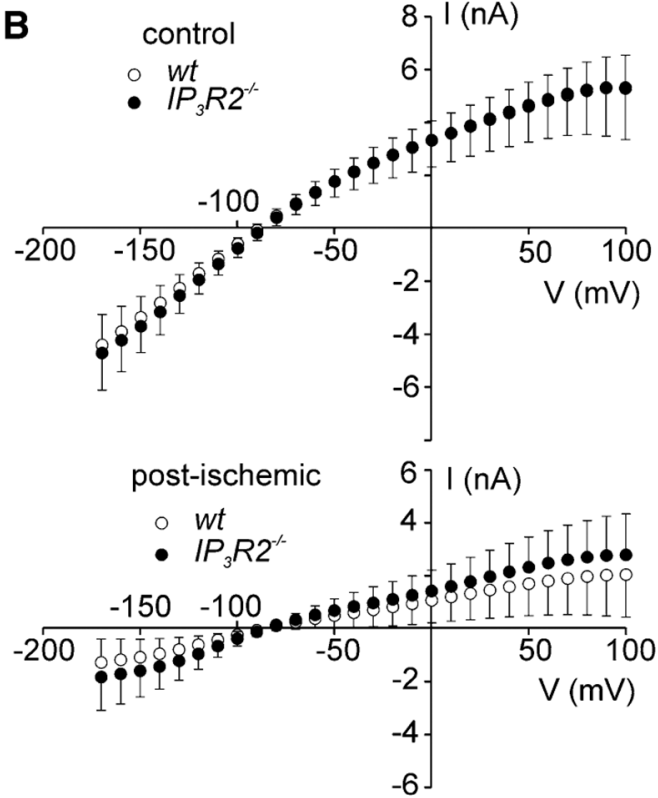

Fig. 4.

Decrease of membrane currents in Müller cells from wild type ( $w t)$ and $I P_{3} R 2^{-1-}$ mice after ischemia. a Examples of whole-cell $\mathrm{K}^{+}$currents recorded in Müller cells. The cells were isolated from untreated control retinae and from retinae that were obtained 7 days after transient retinal ischemia of $90 \mathrm{~min}$. The currents were evoked by depolarizing and hyperpolarizing voltage steps with $20 \mathrm{mV}$ increment from a holding potential of $-80 \mathrm{mV}$ (voltage protocol given in the inset). Outward currents are depicted upwardly, inward currents are depicted downwardly. b Current-voltage relationships of voltage-clamped Müller cells from control and postischemic retinae. Mean values with standard deviations from 25 to 30 cells (5-6 animals) are shown. Current amplitudes were recorded at the end of the voltage steps 

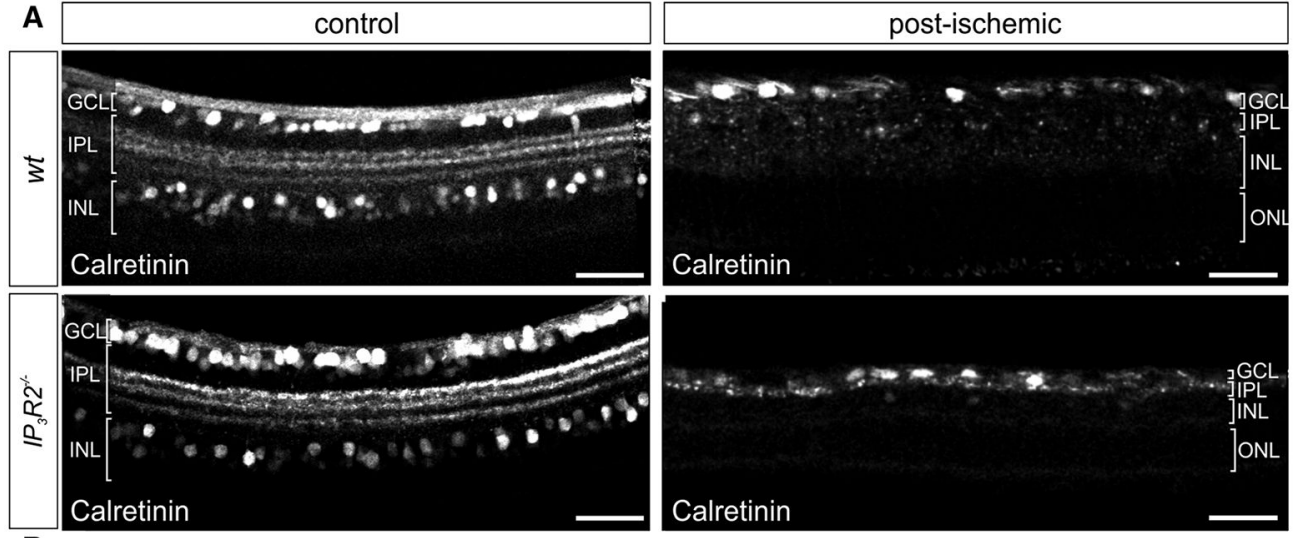

B
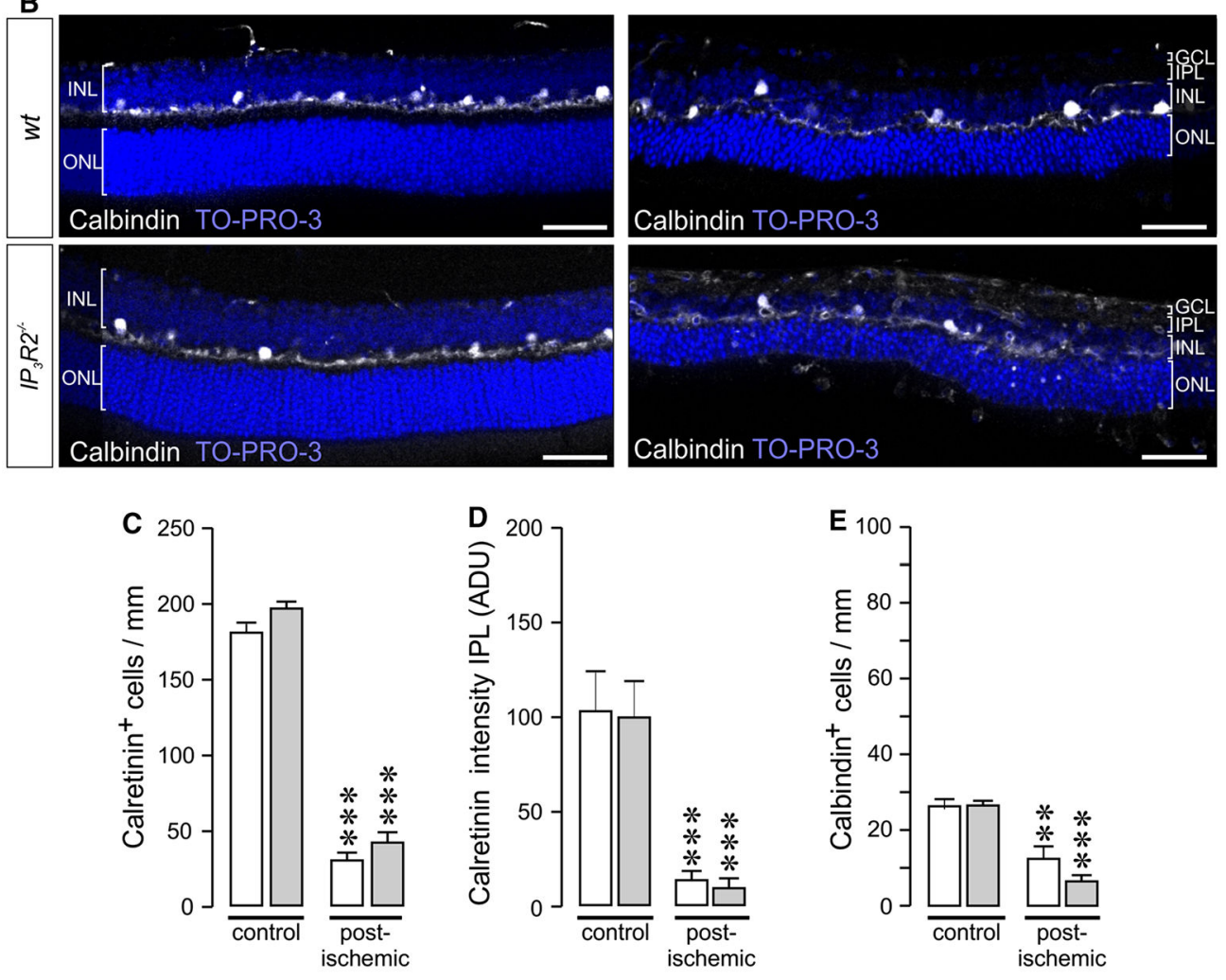

Fig. 5.

Effects of transient ischemia on retinal neurons of wild type ( $w t)$ and $I P_{3} R 2^{-/-}$mice. The tissues were isolated 7 days after retinal ischemia of $90 \mathrm{~min}$. a Calretinin immunoreactivity was mainly found in cell bodies in the inner part of the inner nuclear layer (INL), in the ganglion cell layer (GCL) and in three bands in the inner plexiform layer (IPL). No obvious difference was observed between retinae of $w t$ and $I P_{3} R 2^{-1-}$ mice under control conditions (left). Ischemia resulted in a marked reduction of the calretinin staining of distinct cell bodies and a disappearance of the calretinin-labeled bands in the IPL (right). b Immunolabeling for calbindin displayed an expression in horizontal cells in the INL and a reduced immunoreactivity in the postischemic retinae. For better orientation within the retinal slice nuclei were co-stained with TO-PRO-3. c Mean \pm SEM number of calretinin- 
positive cells counted in the INL and GCL. $\mathbf{d}$ Mean \pm SEM relative intensity of calretinin immunoreactivity in the IPL, reflecting the calretinin content of amacrine cell dendrites. The data were obtained in a 460- $\mu \mathrm{m}$ wide area. e Mean \pm SEM number of calbindin-positive horizontal cells. c-e Data were obtained by analysis of 10-14 central retinal slices derived from 3 to 4 animals. Significant difference to values from the respective untreated control: $* * P<0.01$; *** $P<0.001$. Scale bars $20 \mu \mathrm{m}$. ADU, arbitrary digital units; ONL, outer nuclear layer 

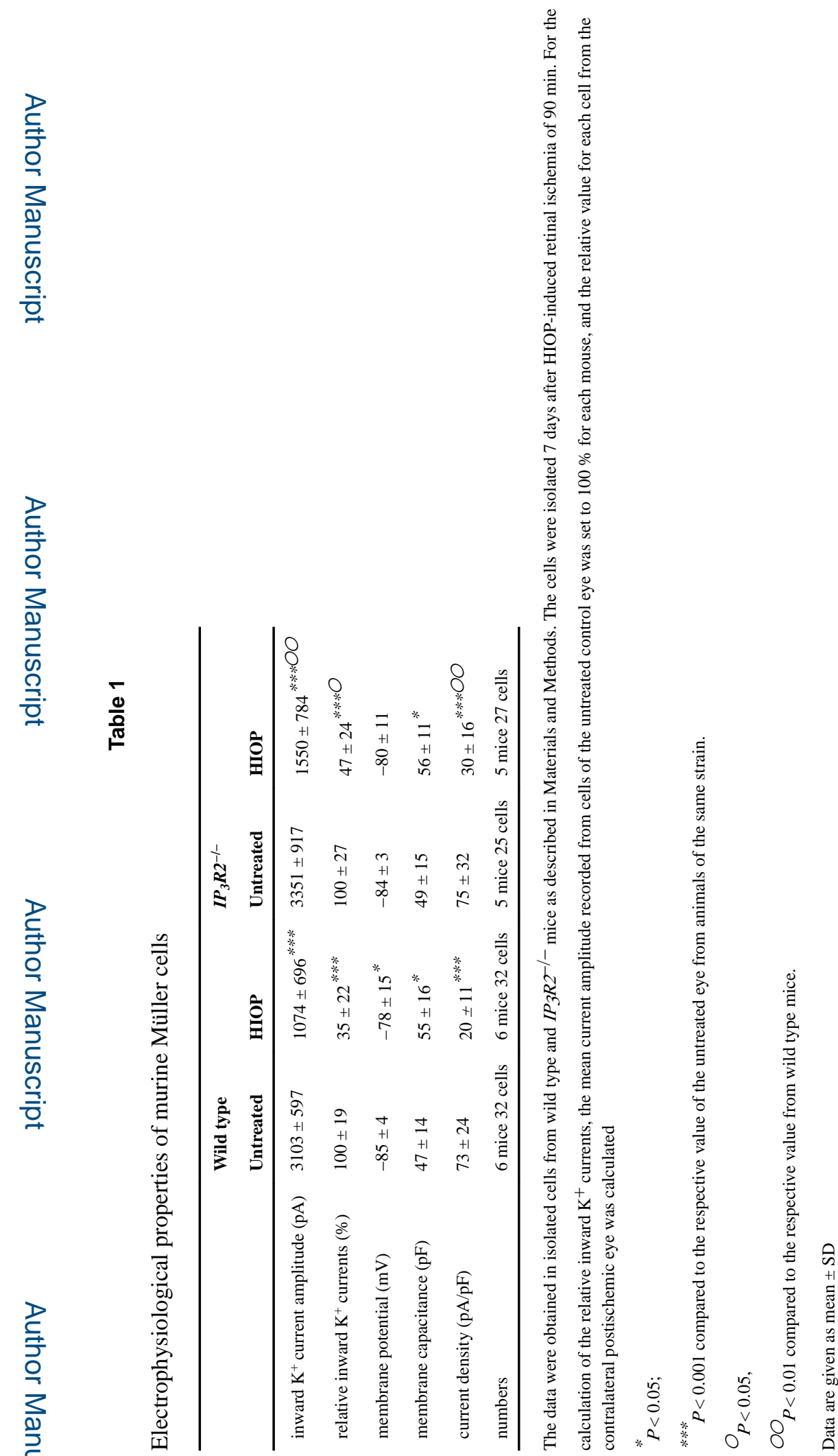

Neurochem Res. Author manuscript; available in PMC 2019 May 25. 